\title{
Knowledge, Attitude and Practice Survey on COVID-19 in Newly Merged Districts of Khyber Pakhthunkhwa Pakistan.
}

\author{
Muhammad Arsalan ${ }^{1}$, Saima Afaq ${ }^{2}$, Nosheen Khan ${ }^{1}$, Zia ul Haq ${ }^{3}$, Wagmah Khan ${ }^{1}$, and \\ Hira Jamil ${ }^{1}$ \\ ${ }^{1}$ Affiliation not available \\ ${ }^{2}$ Imperial College London Faculty of Medicine \\ ${ }^{3}$ Khyber Medical University
}

July 2, 2020

\begin{abstract}
Background: Newly Merged Districts (NMDs) of erstwhile FATA Pakistan area has remained under protracted emergency of conflict and terrorism and has difficult terrain with hard to reach areas. Methods: We conducted KAP survey about COVID19 in five NMDs, aiming at assessing knowledge of population and establishing baseline for comparison. A total of 1227 respondents (376 adult males, 382 adult females, 236 adolescent boys and 233 adolescent girls) were interviewed in 150 locations over a period of five days. Data Instruments were pretested, and consent of respondents were taken. Multiple choice options were given to choose from; hence responses have been calculated. Results: Our results reveal that mean knowledge score was similar amongst adults and adolescents. However, adult males on average scored better than the adult females. Overall, $98 \%$ of the study participants knew about COVID 19 and 92\% participants acknowledged COVID- 19 as a preventable infection. Formal school education and belonging to district NWTD and SWTD (vs. the reference district Khyber) were significantly associated with higher knowledge score amongst both adults and adolescents. In addition, formal school education and adults belonging to district Kurram, Orakzai and SWTD (vs. the reference district Khyber) had greater odds of believing that COVID 19 is preventable. Conclusion: Our findings confirm that majority of respondents know about symptoms, spread, prevention, test and treatment related to COVID 19 which may be attributed to concurrent global, national and provincial information dissemination campaigns.
\end{abstract}

\section{Knowledge, Attitude and Practice Survey on COVID-19 in Newly Merged Districts of Khyber Pakhthunkhwa Pakistan.}

Muhammad Arsalan ${ }^{1}$, Saima Afaq ${ }^{2,3}$, Nosheen Khan ${ }^{5}$, Zia ul Haq ${ }^{2}$, Wagmah Javed Khan ${ }^{4}$ and Hira Jamil ${ }^{1}$

1. Khyber Medical College, Peshawar, Pakistan.

2. Institute of Public health and Social Sciences, Khyber Medical University, Peshawar, Pakistan.

3. School of Public Health, Imperial College London, UK.

4. Khyber Girls Medical College Peshawar, Pakistan.

5. Ayub Medical College Abbott Abad.

Author for correspondence

Muhammad Arsalan

Email: marsalankmc@gmail.com 


\section{Abstract}

Background: Newly Merged Districts (NMDs) of erstwhile FATA Pakistan area has remained under protracted emergency of conflict and terrorism and has difficult terrain with hard to reach areas.

Methods: We conducted KAP survey about COVID19 in five NMDs, aiming at assessing knowledge of population and establishing baseline for comparison. A total of 1227 respondents (376 adult males, 382 adult females, 236 adolescent boys and 233 adolescent girls) were interviewed in 150 locations over a period of five days. Data Instruments were pretested, and consent of respondents were taken. Multiple choice options were given to choose from; hence responses have been calculated.

Results: Our results reveal that mean knowledge score was similar amongst adults and adolescents. However, adult males on average scored better than the adult females. Overall, $98 \%$ of the study participants knew about COVID 19 and 92\% participants acknowledged COVID- 19 as a preventable infection. Formal school education and belonging to district NWTD and SWTD (vs. the reference district Khyber) were significantly associated with higher knowledge score amongst both adults and adolescents. In addition, formal school education and adults belonging to district Kurram, Orakzai and SWTD (vs. the reference district Khyber) had greater odds of believing that COVID 19 is preventable.

Conclusion: Our findings confirm that majority of respondents know about symptoms, spread, prevention, test and treatment related to COVID 19 which may be attributed to concurrent global, national and provincial information dissemination campaigns.

Keywords: COVID 19, pandemic, Influenza, KAP, Pakistan, South Asia, knowledge

\section{Background:}

In December 2019, a series of pneumonia cases of unknown cause were detected in Wuhan City, Hubei Province of China. The pathogen identified was named as novel coronavirus (2019-nCoV), currently called, severe acute respiratory syndrome corona virus-2 (SARS-CoV-2), an enveloped and single stranded RNA virus [4] which has phylogenetic resemblance to SARS-COV-1 [5]. COVID-19 is the name that has been given to a new severe acute respiratory syndrome caused by coronavirus 2 (SARS-CoV-2). The disease was notified to the World Health Organization (WHO) on December 31, 2019 [1] and it was declared as public health emergency of international concern (PHEIC) by WHO on January 30, 2020. Due to the rapid spread of the virus, the severity of illness and reported fatalities, COVID-19 was further labelled as a global pandemic on March 11, 2020 [2]. By June 2020 COVID-19 has spread to over 210 countries and territories, caused 6,313,662 laboratory confirmed cases and 376,282 deaths [3]. Till date (June 2020), no medicine has demonstrated efficacy in preventing, treating or curing COVID-19.

Pakistan's first COVID-19 case was reported on 26 February 2020 [7]. As of June 9, 2020, Pakistan has 108,317 laboratory confirmed cases and 2,172 COVID-19 associated deaths. Punjab $(n=40,815)$ has highest number of cases followed by Sindh $(\mathrm{n}=39,555)$, Khyber Pakhtunkhwa KP $(\mathrm{n}=14,006)$, Baluchistan $(\mathrm{n}=6,788)$, Gilgit Baltistan (952), Islamabad $(n=5,785)$ and Azad Jammu Kashmir $(n=412)$ [8]. First systematic response emerged on March 13, when the government convened an emergency meeting of the National Security Committee, an apex civil-military coordination body, and made the decisions to seal the border with Iran, prohibit large-scale public gatherings, institute social distancing to limit infections, and close down educational institutions across the country. The COVID-19 Pakistan Preparedness and Response Plan (PPRP), prepared with the support of the UN and is guided by the WHO Strategic Preparedness and Response Plan (SPRP) [9], outlines the international assistance required by the Government of Pakistan (GoP) to stop the transmission of the pandemic and respond to the emerging public health needs in Pakistan. It is

Accordingly, the Government of the province Khyber Pakhtunkhwa (KPK) has taken all the necessary actions to cope with the situation of COVID-19 in the province [10]. Communication campaign under the title 'RCCE' (Risk Communication and Community Engagement) is under implementation across the province and its review reveals that false public perception due to easing of lockdown by Government has 
resulted in escalation of COVID-19 cases in Pakistan that needs to be addressed through a nationwide enforcement intervention to increase compliance with COVID-19 preventative actions [11].

Ex FATA, now known as Newly Merged Districts (NMDs) is the poorest region of Pakistan. $73 \%$ of its 5 million population lives in poverty compared to a national average of 39\% [12]. Adult literacy stands at $28 \%$ ( $8 \%$ for women) compared to a national average of $57 \%$ ( $43 \%$ for women) [13]. One million, out of 1.8 million children (aged 5-16), are out of school. Many families do not send their girls to school, particularly as they reach puberty. Livelihoods and economic opportunities are limited. Many people live in barren, dry, mountainous areas vulnerable to climate change. Only $10 \%$ of land is fertile and only $7 \%$ currently suitable for farming [14].

This area is inaccessible for online and digital surveys due to security and logistical reasons [18]. Therefore, to tailor the response for this isolated area, this face to face survey was direly needed to assess their knowledge and perceptions regarding the COVID 19 pandemic. Fortunately, Khyber Pakhtunkhwa Merged Districts (KPMD) Support Program is implementing outreach activities under DFID support and the staff and resources being well positioned were utilized for the survey. This survey aimed at assessing the knowledge of residents of Newly merged districts, NMDs, about COVID-19.

\section{Methods}

\section{Sampling technique}

A total of 1,227 respondents were interviewed. The sample size enabled us to determine the proportion of respondents with correct answers with a margin of error of \pm 3 .

A cross sectional survey was conducted using multistage random sampling. In stage 1, five out of the seven NMDs were selected; namely Khyber, Kurram, Orakzai, North Waziristan and South Waziristan. In stage 2 , three subdivisions were selected in each district followed by selection of two populous hubs of more than 15,000 population in each subdivision during stage 3 . In stage 4, five villages were selected in each populous hub. Respondents were selected from those coming to outreach session. The selection is best illustrated in Figure 1 .

\section{Data collection:}

Sixty (30 male and 30 female) Health Hygiene Promoters of Department of Health were engaged to collect data using a structured questionnaire. The health promoters were already trained on Covid-19 and were experienced social mobilizers with the equivalent qualification. Orientation was provided on the questionnaire and data collection on April 16, 2020. The health promoters were facilitated by 30 team leaders for logistical and operational needs. Five district managers supervised data collection in the field while the data entry was supervised by the district Management Information System (MIS) assistant.

The questionnaire was designed to capture data on demographics (age, gender, education, address of respondents), the knowledge (symptoms, test, prevention, mode of spread, management and source of information) and attitude (preventable or not) related to the COVID19. Field demonstration was arranged, questionnaire was field tested on $17^{\text {th }}$ April and fine-tuned.

A total of 30 teams were deployed for field data collection. Each team comprised a team leader, one male interviewer and one female interviewer. Teams were provided with appropriate personal protective equipment (PPE) including face masks, hand sanitizers and gloves for the field days. Masks were also provided for the respondents and it was ensured that teams observe social distancing measures during interviews.

Each team had to conduct 8 face to face interviews per day in 30 different settlements. On average, 240 interviews were completed per day; men and boys were interviewed by male interviewers whereas being a conservative society, women and girls were interviewed by female interviewers. In each category, first and fourth client coming to outreach session were chosen for interview. As such, a total of 1,227 interviews were completed in five days in 150 hamlets of five districts. Consent form was signed by each respondent before start of the interview. 
Data entry was done daily by MIS assistant in each district. Both hard and soft copies were then transferred to provincial office of Director Health Services NMDs where provincial data analyst conducted $10 \%$ quality check on the entries.

\section{Ethical considerations:}

Request was submitted to DHS NMDs for the permission to conduct this survey using the paraphernalia of the department. Study protocol was submitted with the request which was examined by the authorities of the department and permission was granted. Study protocol and questionnaire were shared with group of provincial and district managers and consent form, questionnaire and spreadsheet were finalized after taking their views into consideration. Ethical and administrative permission was obtained (ref: 10/DHS/MA/KPMD). All participants provided written informed consent.

\section{Statistical analysis}

Data were analyzed using STATA 15. Continuous variables are presented as Mean (SD) while categorical variables as Percentages and numbers. Frequencies of correct knowledge, attitudes and practices answers were described. Total Knowledge scores were classified by demographic characteristics and compared using independent-samples $t$ test and one-way analysis of variance (ANOVA) as appropriate. Multiple linear regression analysis was conducted using all demographic variables as predictors and knowledge score as the outcome to identify factors associated with knowledge. Binary logistic regression analyses were used to identify demographic factors associated with attitude towards the preventable nature of the disease. Unstandardized regression coefficients with standard error, $\beta$ (SE), and odds ratios along with their 95\% confidence intervals, OR $(95 \% \mathrm{CI})$ were used to quantify the associations between predictors and the outcomes. The statistical significance level was set at $\mathrm{p}<0.05$ (two-sided).

\section{Results}

A total of 1227 participants (including 758 adults and 469 adolescents) completed the survey questionnaire. Among this sample, the average age was 34(12) years and 15(2) years for adults and adolescents respectively. There was almost an equal proportion of males and females (adults: [376 male and 382 females]; adolescents: [233 boys and 236 girls]). Similarly, a comparable number of adults and adolescents participated in the survey from each of the 5 districts (Table 1 ).

Comparison of Mean Knowledge score by demographic characteristics of participants are presented in Table 1. Overall there was no significant difference in Mean score between adults and adolescents (13.78 (4.00), 13.55 (3.72) respectively, $\mathrm{p}=0.3)$. Comparisons within the subgroups of adults showed that the Mean score of males 14.42 (3.89) was significantly higher than that of the females $13.16(4.00) \mathrm{p}<0.001$. Adult participants with any formal education had more knowledge compared to those who had no formal education 14.92 (3.84) and 13.04 (3.93) respectively, $\mathrm{p}<0.001)$. In contrast, both male and female adolescents had similar mean knowledge score $(\mathrm{p}=0.06)$. However, adolescents who had any formal education had significantly better knowledge score than the counterparts $(\mathrm{p}<0.001)$.

A one way between groups ANOVA was performed to compare the impact of 'district of residence' on 'Mean Knowledge score' (Table 1 ). Participants were divided into 5 groups according to the district where the participants lived. There was statistically significant difference in the knowledge score amongst the districts in both adults $(\mathrm{p}<0.001)$ and adolescents $(\mathrm{p}=0.001)$. The magnitude of the difference in the mean score was, however, small. Amongst adults, post hoc comparisons using the Tukey HSD test indicated that the mean score for districts NWTD 15.08 (3.26) and SWTD 15.03 (3.64) were not statistically different from each other, though, these were significantly higher than the mean score of districts Khyber 13.03 (3.46) Kurram 12.36 (4.59) and Orakzai 13.67 (4.18). The mean scores of districts Khyber, Kurram and Orakzai were alike. Amongst adolescents, participants from district NWTD had significantly higher score 13.86 (3.64) compared 
to all other 4 districts, which had similar scores 12.73 (3.05), 13.05 (4.68), 13 (3.78), 13.86 (3.64) for district Khyber, Kurram, Orakzai and SWTD respectively.

Table 2, 3 and 4 present the gender stratified response of participants (adults and adolescents) for various questions used for assessing the knowledge for COVID 19. Overall, $98 \%$ of the study participants knew about COVID 19. Most of the adult and adolescent participants identified fever (63\%) and cough (65\%) as the symptoms of COVID 19 (Table 2 ). Another $44 \%$ of participants identified sore throat while headache and difficulty in breathing was identified by $32 \%$ and $25 \%$ of the participants, respectively. Around $8 \%$ of participants knew about other symptoms, like gastrointestinal tract symptoms, loss of taste and loss of smell. On average around $71 \%$ of the total participants recognized handshake as a mode of transmission (Table 2 ) of COVID19 while the proportion of participants who knew about cough, air borne transmission and overcrowding were $49 \%, 30 \%$ and $18 \%$ respectively. When asked about the treatment options for COVID 19, $68 \%$ opted for consulting a doctor, $26 \%$ for self-cure, $23 \%$ for home remedies while $7 \%$ for spiritual healers. Around $7 \%$ of participants did not know about the treatment (Table 3 ). Typically, $92 \%$ participants acknowledged COVID 19 as a preventable infection while $8 \%$ thought otherwise. Of those who knew it is preventable, $64 \%$ identified hand washing as a method for preventing the infection, $57 \%$ identified home stay whereas social distancing and avoiding handshake was identified by $37 \%$ of participants as an approach for preventing COVID 19. Approximately, $14 \%$ were of view that eating healthy can prevent the infection (Table 3 ). 79\% respondents knew that test is available for its diagnosis. Among those who knew, $55 \%$ were adults and $45 \%$ adolescents, $51 \%$ males and $49 \%$ females. Amongst both adults and adolescents, main source of information was radio $(54 \%)$. The proportion of participants who recognized television, health workers, relatives, social media and newspaper as sources of information about COVID 19 were $30 \%, 29 \%, 26 \%$, $18 \%$ and $7 \%$ respectively. Only $4 \%$ referred to displayed material (Table 4 ). Knowledge of participants significantly differed across genders amongst both adults and adolescents (Tables 2, 3 and 4 ).

Multiple linear regression analysis, adjusted for demographic variables with Knowledge score as the outcome

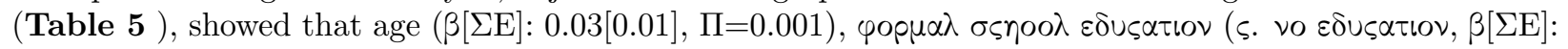

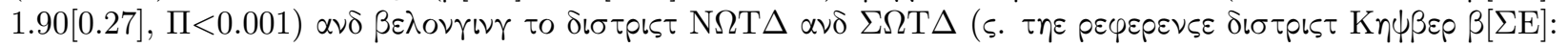

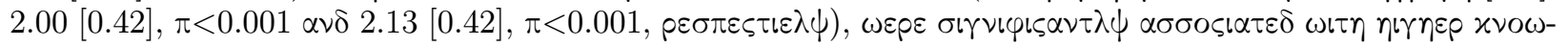

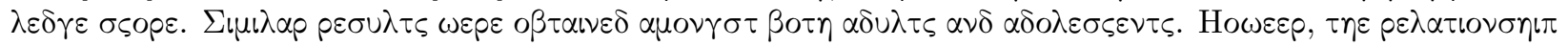

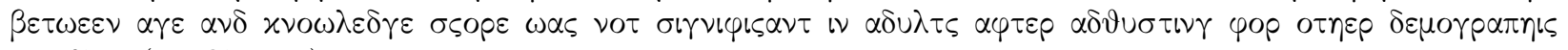
$\alpha p \iota \alpha \lambda \varepsilon(T \alpha \beta \lambda \varepsilon 5)$.

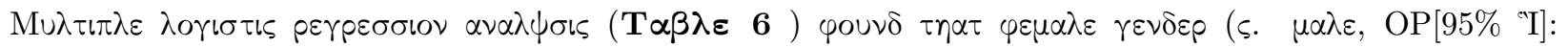

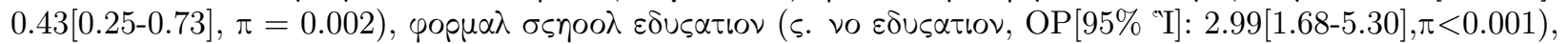

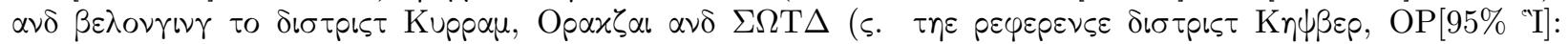

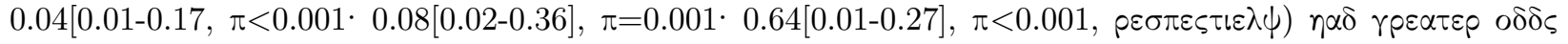

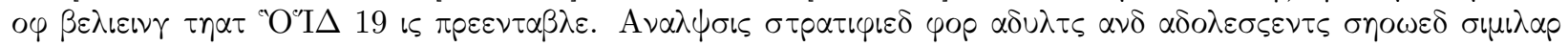

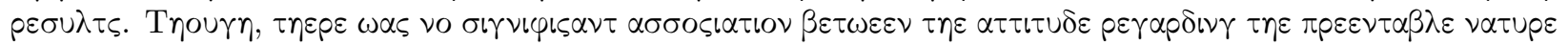

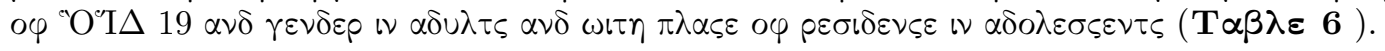

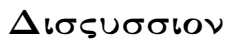

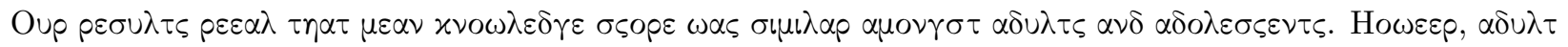

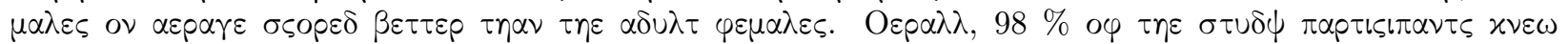

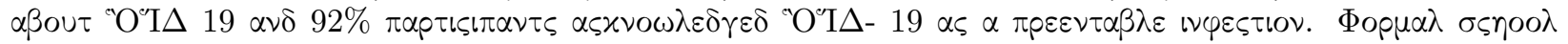

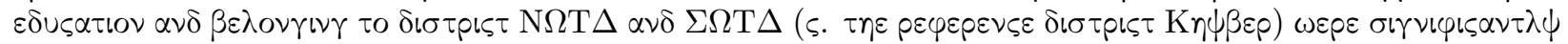

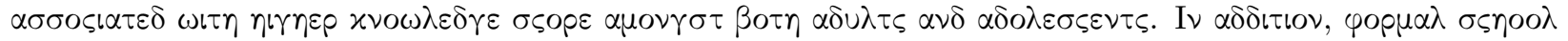

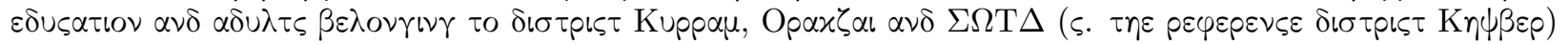

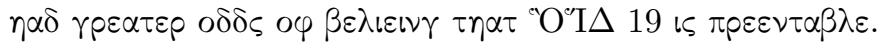

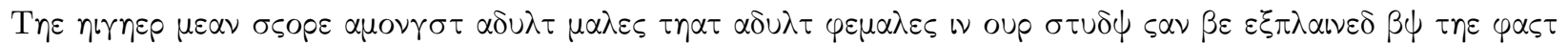

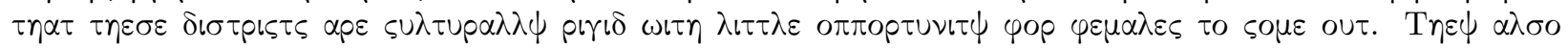

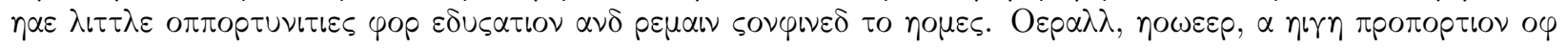




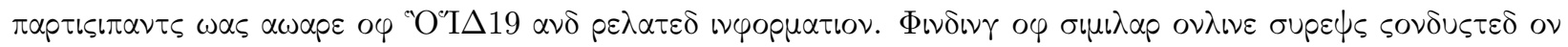

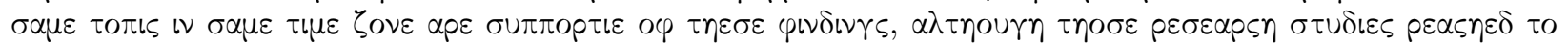

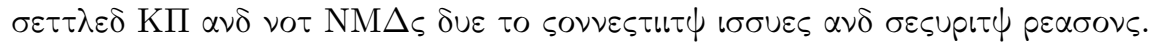

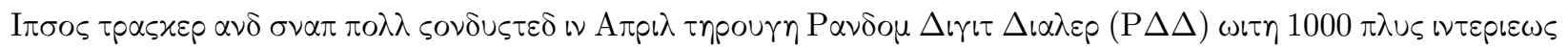

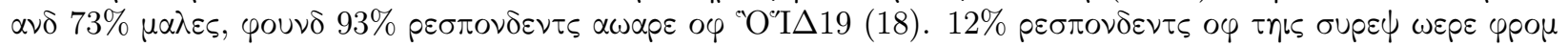

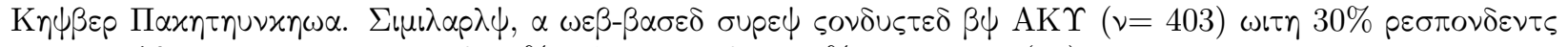

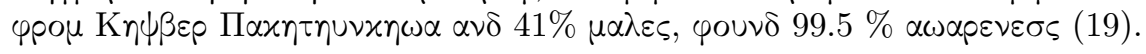

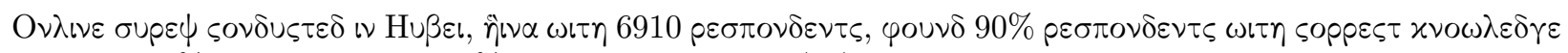
о

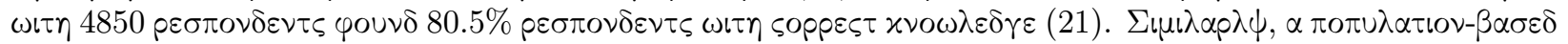

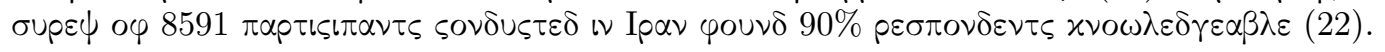

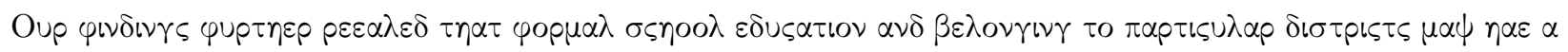

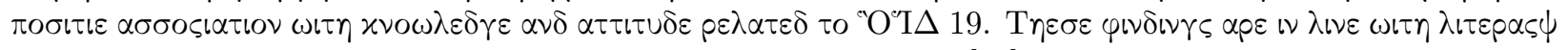

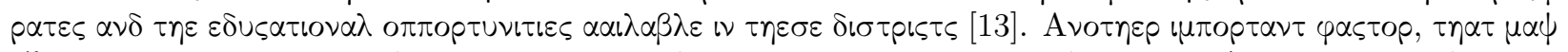

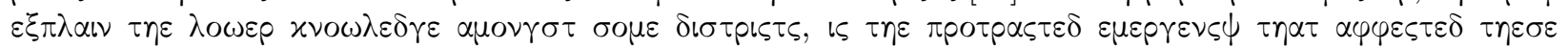
$\delta เ \sigma \tau \rho ı \tau \varsigma ~ เ \nu \tau \varepsilon \nu \sigma \varepsilon \lambda \psi \alpha \nu \delta$

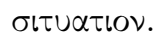

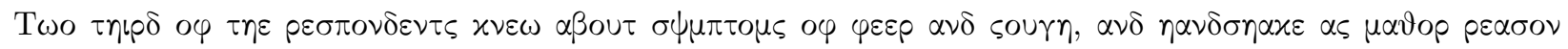

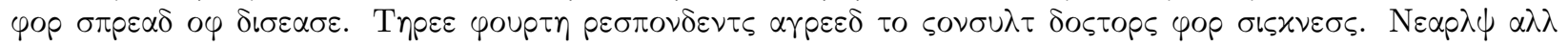

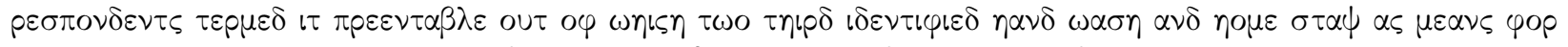

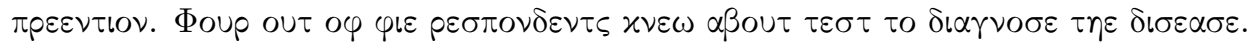

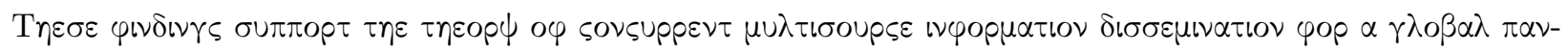

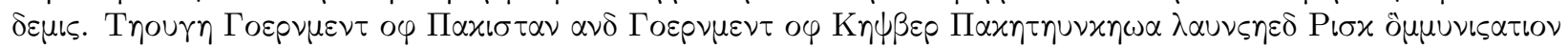

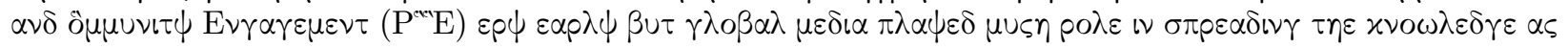

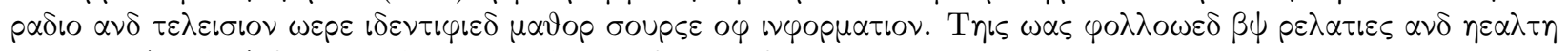

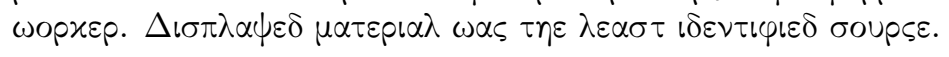

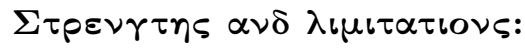

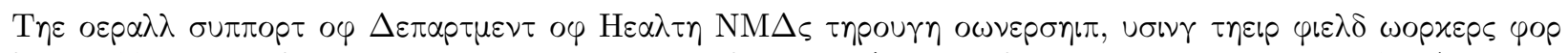

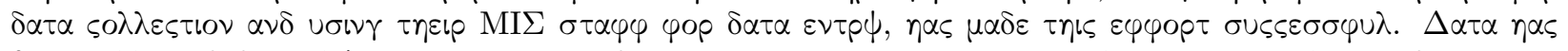

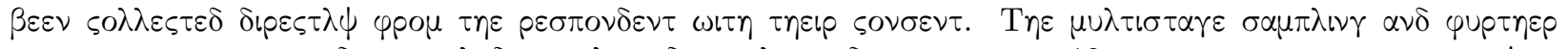

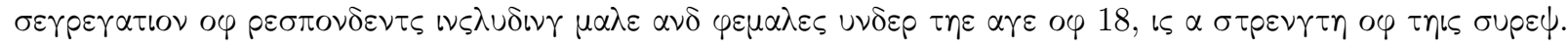

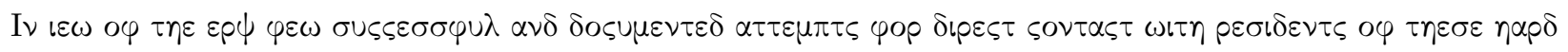

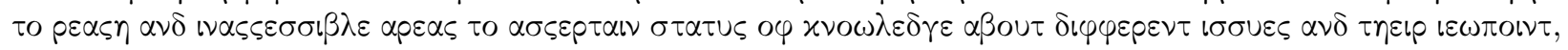

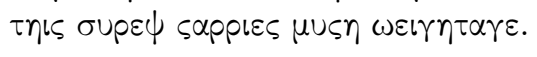

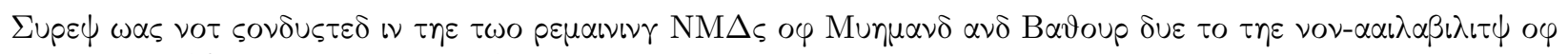

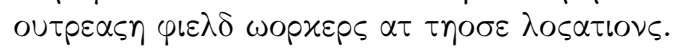

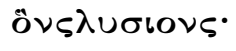

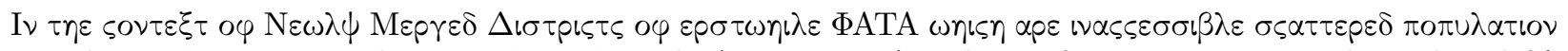

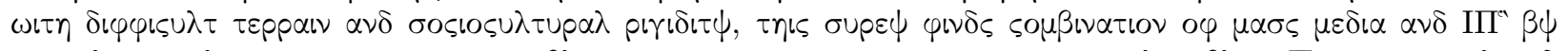

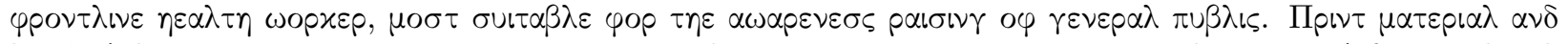

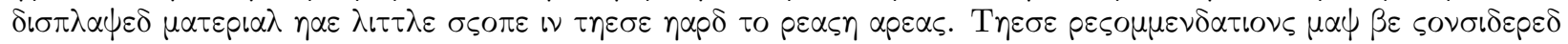

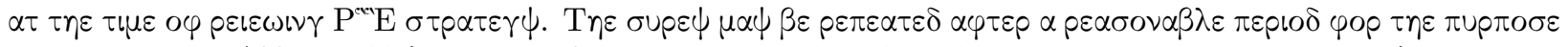

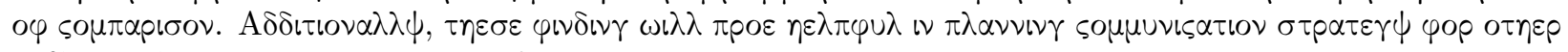

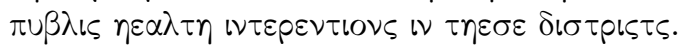

\section{A $\varkappa \nu ० \omega \lambda \varepsilon \delta \gamma \varepsilon \mu \varepsilon \nu \tau:$}




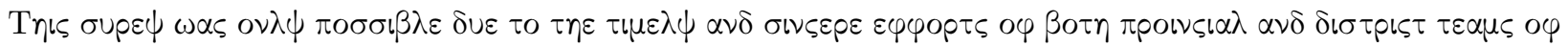

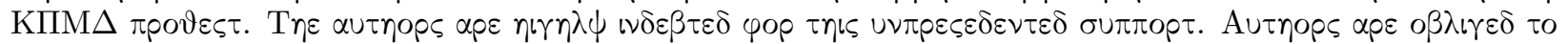

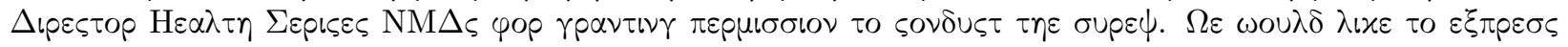

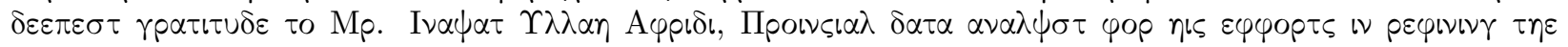

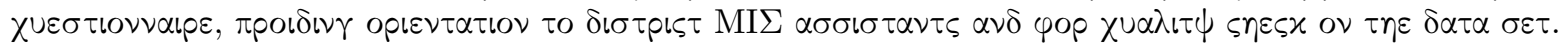

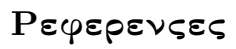

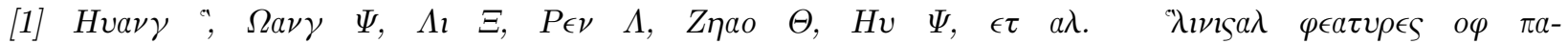

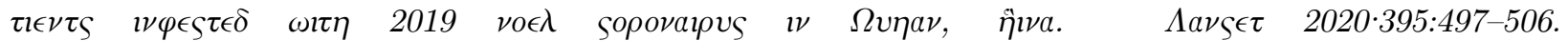
$\eta \tau \tau \pi \varsigma: / / \omega \omega \omega . \tau \eta \epsilon \lambda a \nu_{S} \epsilon \tau . S_{S} \mu / \pi \delta \varphi S / \vartheta o v \rho \nu a \lambda_{S} / \lambda a \nu_{S} \epsilon \tau / \Pi I I \Sigma 0140-6736(20) 30183-5 . \pi \delta \varphi$

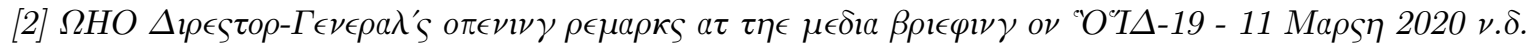

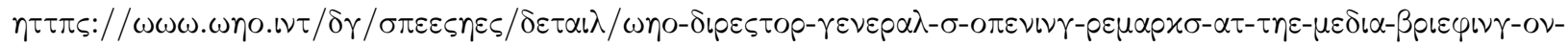

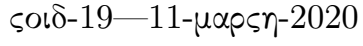

[3] $\eta \tau \tau \pi: / / \varsigma o l \delta . \gamma o . \pi \kappa / \sigma \tau a \tau \varsigma / \gamma \lambda o \beta a \lambda(a \varsigma \varsigma \epsilon \sigma \sigma \epsilon \delta \Theta v \nu \epsilon 2,2020)$

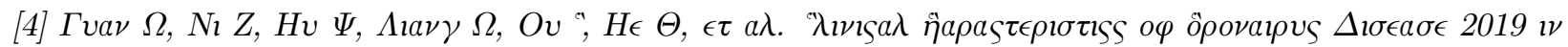

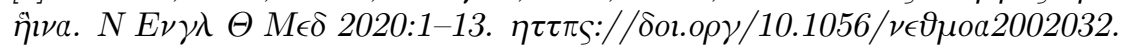

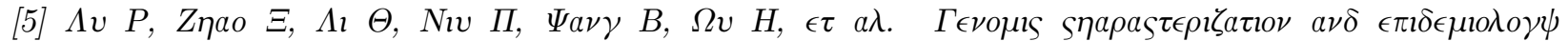

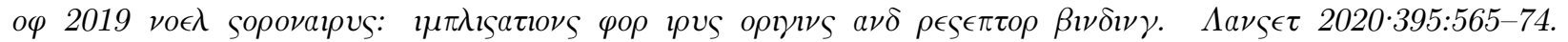
$\eta \tau \tau \pi \varsigma: / / \delta o l . o \rho \gamma / 10.1016 / \Sigma 0140-6736(20) 30251-8$.

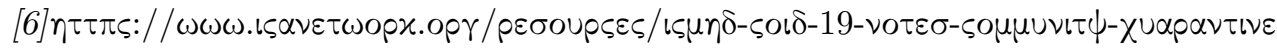

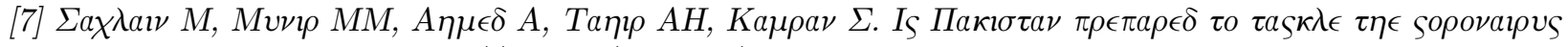
$\epsilon \pi \imath \epsilon \epsilon \iota \varsigma ; 2020 \cdot 36: 213-4$. $\eta \tau \tau \pi \varsigma: / / \delta o \imath . o \rho \gamma / 10.1007 / \sigma 40267-020-00721-1$.

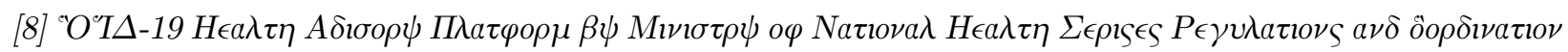

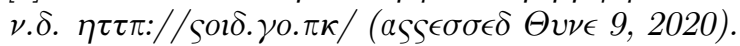

[9] $\eta \tau \tau \pi \varsigma: / / v \nu l \varsigma . o \rho \gamma . \pi \kappa / \varphi \imath \lambda \epsilon \varsigma / 2020 / 03 / \Pi A K I \Sigma T A N-\Pi \rho \epsilon \pi a \rho \epsilon \delta \nu \epsilon \sigma \sigma-\alpha \nu \delta-P \epsilon \sigma \pi o \nu \sigma \epsilon-\Pi \lambda \alpha \nu-\Pi \Pi P \Pi$ - 'O'Т ${ }^{\circ} \Delta-19 . \pi \delta \varphi$

[10] $\eta \tau \tau \pi \varsigma: / / \omega \omega \omega . \tau \eta \epsilon \nu \epsilon \omega \varsigma . \varsigma о \mu . \pi \kappa / \pi \rho \imath \nu \tau / 623369-\kappa \pi-\gamma o \tau-\sigma \omega \imath \nu \gamma \sigma-\imath \nu \tau o-\alpha \varsigma \tau \imath o \nu-\tau o-\delta \epsilon a \lambda-\omega \imath \tau \eta-\varsigma o \imath \delta-19$

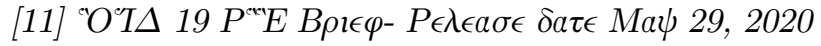

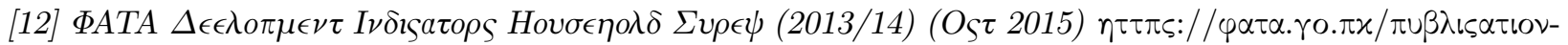
$\delta \varepsilon \tau \alpha \iota \lambda \varsigma . \pi \eta \pi ; \iota \delta=59$

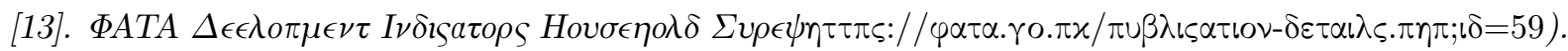

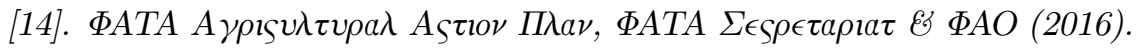

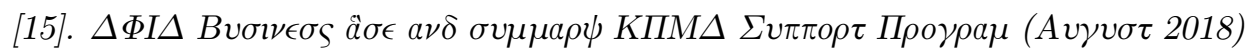

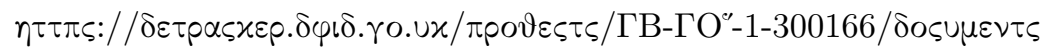

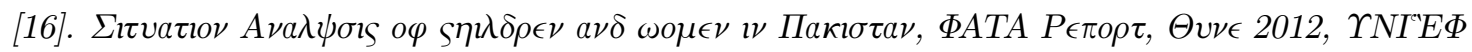

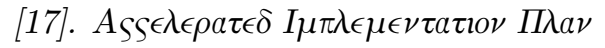

$\eta \tau \tau \pi \varsigma: / / \omega \omega \omega . \delta \rho \circ \pi \beta \beta^{\prime} \xi . \varsigma \circ \mu / \varsigma / \lambda 8 \alpha \lambda 0 \vartheta \delta \sigma \gamma \gamma \varphi \vartheta \eta 3 / \Delta \rho \alpha \varphi \tau \% 20 \mathrm{AI \Pi} \% 20 \% 3 . \pi \delta \varphi ; \delta \lambda=0$

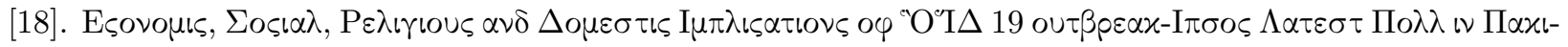

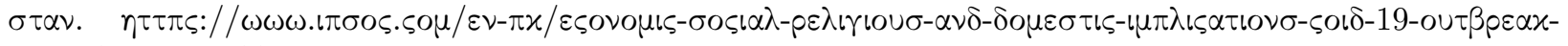
$\iota \pi \sigma o \sigma-\lambda \alpha \tau \varepsilon \sigma \tau-\pi 0 \lambda \lambda-\pi \alpha x \iota \sigma \tau \alpha \nu$

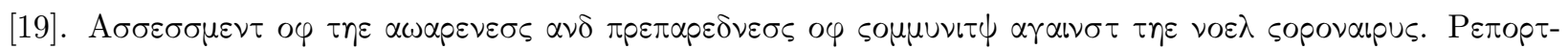

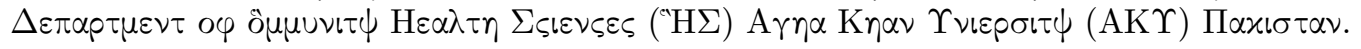




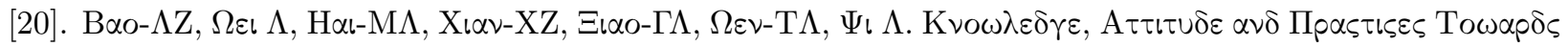

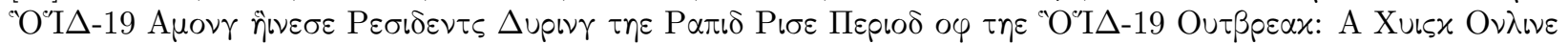

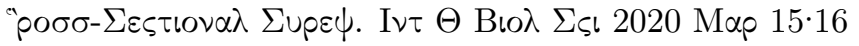

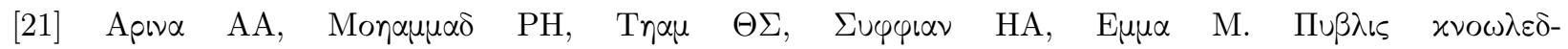

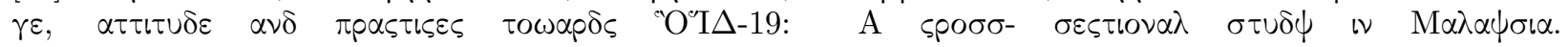

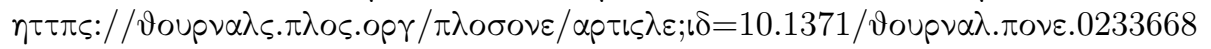

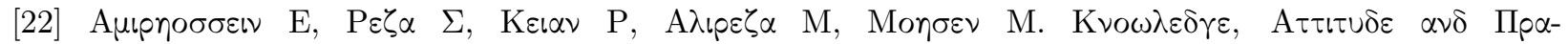

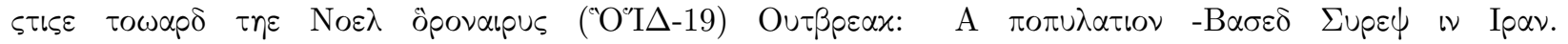
$\eta \tau \tau \pi \varsigma: / / \omega \omega \omega . \omega \eta \sigma . \iota \tau \tau / \beta \cup \lambda \lambda \varepsilon \tau \tau \nu / o v \lambda เ \nu \varepsilon_{-} \varphi \iota \rho \sigma \tau / 20-256651 . \pi \delta \varphi$

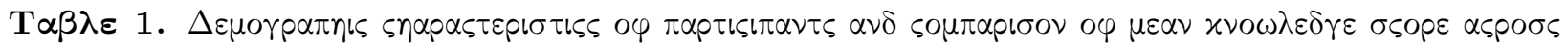

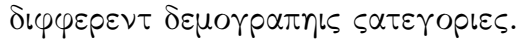

\begin{tabular}{|c|c|c|c|c|c|c|c|}
\hline \multicolumn{2}{|c|}{ CharacteristicAdults } & \multirow{2}{*}{$\begin{array}{l}\text { Adults } \\
\text { Score } \\
{[\text { Mean }} \\
\text { (SD)] }\end{array}$} & \multicolumn{2}{|l|}{ Adults } & \multirow{2}{*}{$\begin{array}{l}\text { Adolescents } \\
\mathrm{n}(\%)\end{array}$} & \multirow{2}{*}{$\begin{array}{l}\text { Adolescents } \\
\text { Score } \\
{[\text { Mean }} \\
(\mathrm{SD})]\end{array}$} & \multirow{2}{*}{$\frac{\text { Adolescents }}{\mathrm{p}}$} \\
\hline & $\mathrm{n}(\%)$ & & $\mathrm{p}$ & & & & \\
\hline $\begin{array}{l}\text { Age } \\
\text { group }\end{array}$ & $\begin{array}{l}\text { Age } \\
\text { group }\end{array}$ & $\begin{array}{l}\text { Age } \\
\text { group }\end{array}$ & $\begin{array}{l}\text { Age } \\
\text { group }\end{array}$ & $\begin{array}{l}\text { Age } \\
\text { group }\end{array}$ & $\begin{array}{l}\text { Age } \\
\text { group }\end{array}$ & $\begin{array}{l}\text { Age } \\
\text { group }\end{array}$ & $\begin{array}{l}\text { Age } \\
\text { group }\end{array}$ \\
\hline $\begin{array}{l}\text { Adults vs } \\
\text { adolescents }\end{array}$ & $758(62 \%)$ & $\begin{array}{l}13.78 \\
(4.00)\end{array}$ & & & $469(38 \%)$ & $\begin{array}{l}13.55 \\
(3.72)\end{array}$ & $0.3^{*}$ \\
\hline Gender & Gender & Gender & Gender & Gender & Gender & Gender & Gender \\
\hline Male & $\begin{array}{l}376 \\
(49.6 \%)\end{array}$ & $\begin{array}{l}14.42 \\
(3.89)\end{array}$ & $>0.001$ & & $\begin{array}{l}233 \\
(49.6 \%)\end{array}$ & $13.88(3.55)$ & 0.06 \\
\hline Female & $\begin{array}{l}382 \\
(50.3 \%)\end{array}$ & $\begin{array}{l}13.16 \\
(4.00)\end{array}$ & & & $\begin{array}{l}236 \\
(50.3 \%)\end{array}$ & $13.23(3.86)$ & \\
\hline Education & Education & Education & Education & Education & Education & Education & Education \\
\hline $\begin{array}{l}\text { No formal } \\
\text { education }\end{array}$ & $\begin{array}{l}458 \\
(60.4 \%)\end{array}$ & $\begin{array}{l}13.04 \\
(3.93)\end{array}$ & $>0.001$ & & $\begin{array}{l}201 \\
(42.9 \%)\end{array}$ & $\begin{array}{l}12.81 \\
(3.71)\end{array}$ & $>0.001$ \\
\hline $\begin{array}{l}\text { Any } \\
\text { formal } \\
\text { education }\end{array}$ & $\begin{array}{l}300 \\
(39.6 \%)\end{array}$ & $\begin{array}{l}14.92 \\
(3.84)\end{array}$ & & & $\begin{array}{l}268 \\
(57.1 \%)\end{array}$ & $\begin{array}{l}14.10 \\
(3.63)\end{array}$ & \\
\hline$* *$ District & **District & **District & $* *$ District & **District & $* *$ District & ${ }^{* *}$ District & $* *$ District \\
\hline $\begin{array}{l}\text { of } \\
\text { residence }\end{array}$ & $\begin{array}{l}\text { of } \\
\text { residence }\end{array}$ & $\begin{array}{l}\text { of } \\
\text { residence }\end{array}$ & $\begin{array}{l}\text { of } \\
\text { residence }\end{array}$ & $\begin{array}{l}\text { of } \\
\text { residence }\end{array}$ & $\begin{array}{l}\text { of } \\
\text { residence }\end{array}$ & $\begin{array}{l}\text { of } \\
\text { residence }\end{array}$ & $\begin{array}{l}\text { of } \\
\text { residence }\end{array}$ \\
\hline Khyber & $\begin{array}{l}171 \\
(22.6 \%)\end{array}$ & $\begin{array}{l}13.03 \\
(3.46)\end{array}$ & $>0.001$ & & $69(14.7 \%)$ & $\begin{array}{l}12.73 \\
(3.05)\end{array}$ & 0.001 \\
\hline Kurram & $\begin{array}{l}161 \\
(21.2 \%)\end{array}$ & $\begin{array}{l}12.36 \\
(4.59)\end{array}$ & & & $79(16.9 \%)$ & $\begin{array}{l}13.05 \\
(4.68)\end{array}$ & \\
\hline NWTD & $\begin{array}{l}141 \\
(18.6 \%)\end{array}$ & $\begin{array}{l}15.08 \\
(3.26)\end{array}$ & & & $99(21.1 \%)$ & $\begin{array}{l}14.77 \\
(2.95)\end{array}$ & \\
\hline Orakzai & $\begin{array}{l}132 \\
(17.4 \%)\end{array}$ & $\begin{array}{l}13.67 \\
(4.18)\end{array}$ & & & $\begin{array}{l}108 \\
(23.0 \%)\end{array}$ & $13(3.78)$ & \\
\hline SWTD & $\begin{array}{l}153 \\
(20.2 \%)\end{array}$ & $\begin{array}{l}15.03 \\
(3.64)\end{array}$ & & & $\begin{array}{l}114 \\
(24.3 \%)\end{array}$ & $\begin{array}{l}13.86 \\
(3.64)\end{array}$ & \\
\hline
\end{tabular}

\# p value is for comparison of mean score across different demographic categories.

${ }^{*} \mathrm{p}$ value is for comparison of mean score between adults and adolescents. 
** one way ANOVA was performed followed by post hoc Tukey HSD test.

Table 2. Gender stratified knowledge about symptoms and mode of transmission of COVID 19 amongst adults and adolescents.

\begin{tabular}{|c|c|c|c|c|c|c|c|}
\hline $\begin{array}{l}\text { Symptoms } \\
\text { of Covid19 }\end{array}$ & Overall & Adults & Adults & & Adolescents & Adolescents & \\
\hline & & Male & Female & p & Male & Female & $\mathrm{p}$ \\
\hline & 1227 & 376 & 382 & & 233 & 236 & \\
\hline fever & $776(63 \%)$ & $\begin{array}{l}259 \\
(68.9 \%)\end{array}$ & $\begin{array}{l}229 \\
(59.9 \%)\end{array}$ & 0.01 & $\begin{array}{l}149 \\
(63.9 \%)\end{array}$ & $\begin{array}{l}139 \\
(58.9 \%)\end{array}$ & 0.3 \\
\hline headache & $396(32 \%)$ & $\begin{array}{l}109 \\
(29.0 \%)\end{array}$ & $\begin{array}{l}139 \\
(36.4 \%)\end{array}$ & 0.03 & $71(30.5 \%)$ & $77(32.6 \%)$ & 0.6 \\
\hline cough & $793(65 \%)$ & $\begin{array}{l}259 \\
(68.9 \%)\end{array}$ & $\begin{array}{l}234 \\
(61.3 \%)\end{array}$ & 0.03 & $\begin{array}{l}165 \\
(70.8 \%)\end{array}$ & $\begin{array}{l}135 \\
(57.2 \%)\end{array}$ & 0.002 \\
\hline $\begin{array}{l}\text { throat } \\
\text { pain }\end{array}$ & $546(44 \%)$ & $\begin{array}{l}173 \\
(46.0 \%)\end{array}$ & $\begin{array}{l}166 \\
(43.5 \%)\end{array}$ & 0.5 & $\begin{array}{l}101 \\
(43.3 \%)\end{array}$ & $\begin{array}{l}106 \\
(44.5 \%)\end{array}$ & 0.7 \\
\hline $\begin{array}{l}\text { difficulty } \\
\text { in }\end{array}$ & $303(25 \%)$ & $\begin{array}{l}112 \\
(29.8 \%)\end{array}$ & $76(19.9 \%)$ & 0.002 & $58(24.9 \%)$ & $57(24.2 \%)$ & 0.8 \\
\hline $\begin{array}{l}\text { breathing } \\
\text { other }\end{array}$ & $98(8 \%)$ & $34(9.0 \%)$ & $28(7.3 \%)$ & 0.4 & $17(7.3 \%)$ & $19(8.1 \%)$ & 0.7 \\
\hline $\begin{array}{l}\text { total score } \\
(\text { mean } \\
[\mathrm{SD}])\end{array}$ & $2.27(1.01)$ & $2.43(1.03)$ & $2.22(1.11)$ & 0.006 & $2.35(.976)$ & $\begin{array}{l}2.18 \\
(1.102)\end{array}$ & 0.09 \\
\hline $\begin{array}{l}\text { Mode of } \\
\text { transmis- } \\
\text { sion }\end{array}$ & $\begin{array}{l}\text { Mode of } \\
\text { transmis- } \\
\text { sion }\end{array}$ & $\begin{array}{l}\text { Mode of } \\
\text { transmis- } \\
\text { sion }\end{array}$ & $\begin{array}{l}\text { Mode of } \\
\text { transmis- } \\
\text { sion }\end{array}$ & $\begin{array}{l}\text { Mode of } \\
\text { transmis- } \\
\text { sion }\end{array}$ & $\begin{array}{l}\text { Mode of } \\
\text { transmis- } \\
\text { sion }\end{array}$ & $\begin{array}{l}\text { Mode of } \\
\text { transmis- } \\
\text { sion }\end{array}$ & $\begin{array}{l}\text { Mode of } \\
\text { transmis- } \\
\text { sion }\end{array}$ \\
\hline handshake & $877(71 \%)$ & $\begin{array}{l}292 \\
(77.7 \%)\end{array}$ & $\begin{array}{l}246 \\
(64.4 \%)\end{array}$ & $<0.001$ & $\begin{array}{l}180 \\
(77.3 \%)\end{array}$ & $\begin{array}{l}159 \\
(67.4 \%)\end{array}$ & 0.2 \\
\hline cough & $602(49 \%)$ & $\begin{array}{l}199 \\
(52.9 \%)\end{array}$ & $\begin{array}{l}183 \\
(47.9 \%)\end{array}$ & 0.2 & $\begin{array}{l}104 \\
(44.6 \%)\end{array}$ & $\begin{array}{l}116 \\
(49.2 \%)\end{array}$ & 0.3 \\
\hline air & $363(30 \%)$ & $\begin{array}{l}105 \\
(27.9 \%)\end{array}$ & $\begin{array}{l}128 \\
(33.5 \%)\end{array}$ & 0.09 & $57(24.5 \%)$ & $73(30.9 \%)$ & 0.1 \\
\hline congregation & $226(18 \%)$ & $92(24.5 \%)$ & $41(10.7 \%)$ & $<0.001$ & $54(23.2 \%)$ & $39(16.5 \%)$ & 0.07 \\
\hline any other & $84(7 \%)$ & $31(8.2 \%)$ & $19(5.0 \%)$ & 0.07 & $18(7.7 \%)$ & $16(6.8 \%)$ & 0.7 \\
\hline don't & $38(3 \%)$ & $2(0.5 \%)$ & $24(6.3 \%)$ & $<0.001$ & $5(2.1 \%)$ & $7(3.0 \%)$ & 0.5 \\
\hline $\begin{array}{l}\text { know } \\
\text { total score } \\
(\text { mean } \\
[\mathrm{SD}])\end{array}$ & $1.67(0.81)$ & $1.92(0.77)$ & $1.31(0.56)$ & $<0.001$ & $\begin{array}{l}1.794 \\
(0.78)\end{array}$ & $\begin{array}{l}1.737 \\
(0.83)\end{array}$ & 0.4 \\
\hline
\end{tabular}

Table 3. Gender stratified knowledge about treatment options, prevention strategies and availability of test for COVID 19 amongst adults and adolescents.

\begin{tabular}{lllll}
\hline Treatment options & Overall & Adults & Adults & \\
\hline & & Male & Female & p \\
consult doctor & $\mathbf{1 2 2 7}$ & $\mathbf{3 7 6}$ & $\mathbf{3 8 2}$ & \\
home remedies & $829(68 \%)$ & $279(74.2 \%)$ & $234(61.3 \%)$ & $<0.001$ \\
& $278(23 \%)$ & $80(21.3 \%)$ & $98(25.7 \%)$ & 0.1
\end{tabular}




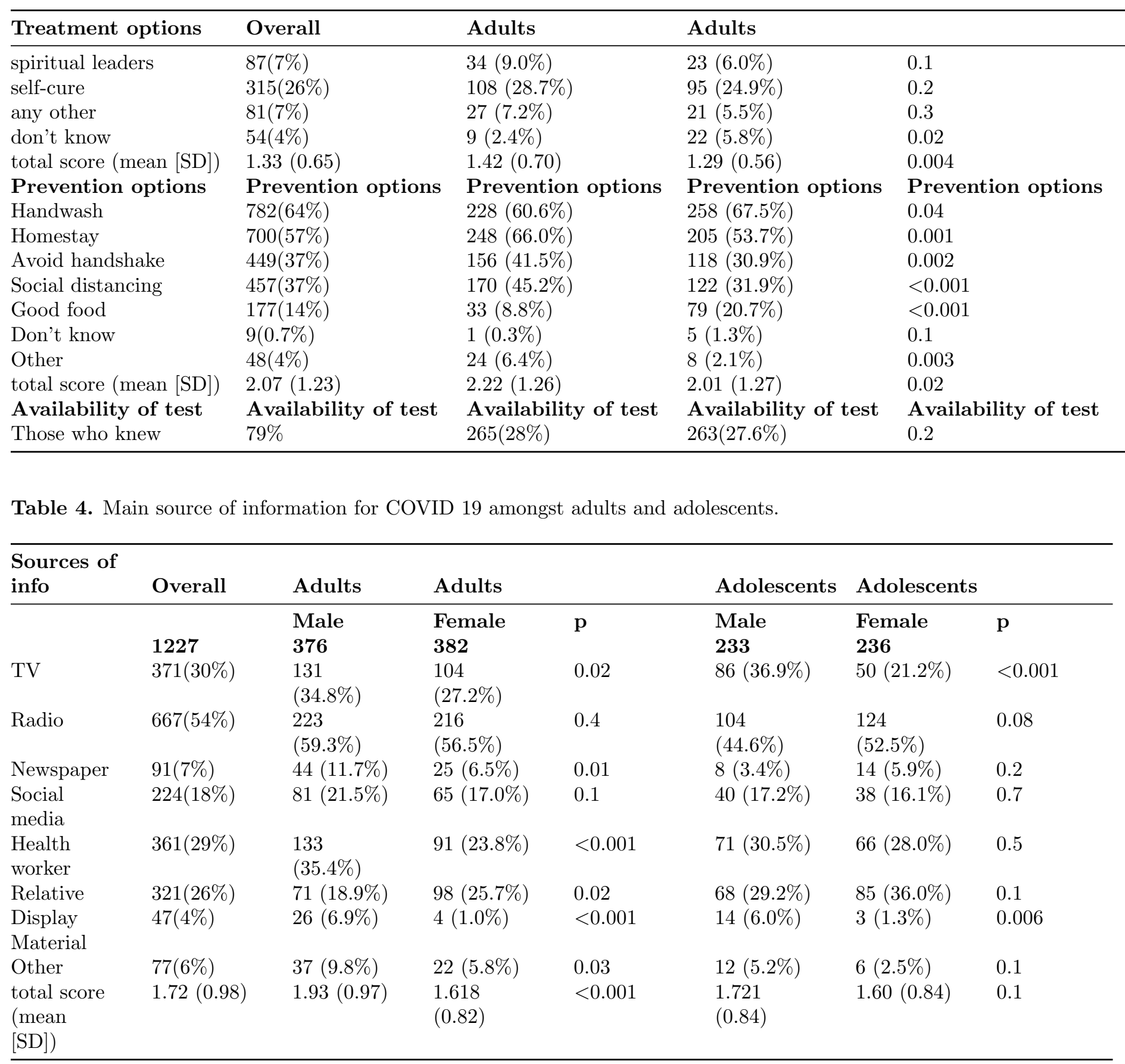

Table 5. Relationship between demographic characteristics and Knowledge score.

\begin{tabular}{lll}
\hline Characteristics & Relationship with Knowledge Score & Relationship with Knowledge Score \\
\hline & B(SE) & $\mathbf{p}$ \\
Overall & Overall & Overall \\
Age & $0.028(.008)$ & 0.001 \\
Sex & $-0.123(0.265)$ & 0.642
\end{tabular}




\begin{tabular}{lll}
\hline Characteristics & Relationship with Knowledge Score & Relationship with Knowledge Score \\
\hline Education & $1.90(.274)$ & $>0.001$ \\
District-Kurram & $-.426(.338)$ & 0.208 \\
District-NWTD & $2.038(.338)$ & $>0.001$ \\
District-Orakzai & $.368(.338)$ & 0.276 \\
District-SWTD & $1.732(.329)$ & $>0.001$ \\
Adults & Adults & Adults \\
Age & $.014(0.11)$ & 0.226 \\
Sex & $0.077(.328)$ & 0.814 \\
Education & $2.003(.344)$ & $>0.001$ \\
District-Kurram & $-.706(.413)$ & 0.087 \\
District-NWTD & $1.999(.426)$ & $>0.001$ \\
District-Orakzai & $.573(.434)$ & 0.188 \\
District-SWTD & $2.134(.418)$ & $>0.001$ \\
Adolescents & Adolescents & Adolescents \\
Age & $0.392(.092)$ & $>0.001$ \\
Sex & $-.402(.444)$ & 0.365 \\
Education & $1.701(.450)$ & $>0.001$ \\
District-Kurram & $.533(.590)$ & 0.367 \\
District-NWTD & $2.198(.556)$ & $>0.001$ \\
District-Orakzai & $.536(.554)$ & 0.334 \\
District-SWTD & $1.403(.541)$ & 0.01 \\
\hline
\end{tabular}

Results are presented as $\mathrm{B}(\mathrm{SE})$ from multiple linear regression adjusting for all demographic variables.

Table 6 . Association between demographic characteristics and attitude towards preventive nature of COVID 19.

\section{Characteristic}

Odds of believing disease is preventable OR $(95 \% \mathrm{CI})$

\begin{tabular}{l}
\hline Overall \\
Age \\
Sex \\
Education \\
District-Kurram \\
District-NWTD \\
District-Orakzai \\
District-SWTD \\
Adults \\
Age \\
Sex \\
Education \\
District-Kurram \\
District-NWTD \\
District-Orakzai \\
District-SWTD \\
Adolescents \\
Age
\end{tabular}

Adults

Adolescents

$1.02(0.99-1.03)$

$0.43(0.25-0.729)$

$2.99(1.68-5.30)$

$0.04(0.01-0.17)$

$0.41(0.08-2.12)$

$0.08(0.02-0.36)$

$0.64(.015-0.27)$

Adults

$1.02(0.99-1.04)$

$0.61(0.32-1.16)$

$2.19(1.07-4.46)$

$0.05(0.01-0.20)$

$0.83(0.11-5.97)$

$0.12(0.03-0.58)$

$0.10(0.02-0.46)$

Adolescents

$1.19(0.98-1.44)$ p

0.08

0.002

$<0.001$

$<0.001$

0.3

0.001

$<0.001$

Adults

0.2

0.1

0.03

$<0.001$

0.8

0.008

0.003

Adolescents

0.06 


\begin{tabular}{lll} 
Characteristic & $\begin{array}{l}\text { Odds of believing } \\
\text { disease is preventable } \\
\text { OR } \mathbf{( 9 5 \% \mathbf { ~ }})\end{array}$ & $\mathbf{p}$ \\
\hline Sex & $0.20(0.07-0.54)$ & 0.002 \\
Education & $5.02(1.86-13.53)$ & 0.001 \\
District-Kurram & $0.45(0.11-1.91)$ & 0.3 \\
District-NWTD & $1.62(0.31-8.50)$ & 0.6 \\
District-Orakzai & $0.44(0.11-1.69)$ & 0.2 \\
District-SWTD & $0.31(0.08-1.13)$ & 0.07 \\
\hline
\end{tabular}

Results are presented as OR (95\% CI) from multiple logistic regression adjusting for all demographic variables.

Figure 1: Multistage Sampling for KAP COVID-19 from the Newly Merged Districts of erstwhile FATA, Pakistan.

\section{Hosted file}

figure 1.docx available at https://authorea.com/users/339251/articles/465474-knowledgeattitude-and-practice-survey-on-covid-19-in-newly-merged-districts-of-khyberpakhthunkhwa-pakistan 